\title{
PREDICTING TURNOVER INTENTION THROUGH ORGANIZATIONAL SUPPORT AND ORGANIZATIONAL COMMITMENT: THE CASE OF A MANUFACTURING COMPANY
}

\author{
SITI ZUBAIDAH OTHMAN \\ School of Business Management \\ Universiti Utara Malaysia \\ NUR SYAFIQAH MOHD SHKURI \\ Department of Business $\mathcal{E}$ Accounting \\ Universiti Tenaga Nasional
}

\begin{abstract}
This paper reports a research that investigated factors that might relate to employees' turnover intention. The study was a cross-sectional study where respondents' perception was measured at one point in time. 105 respondents participated in this study. Two factors, namely organizational support and organizational commitment (affective commitment and continuance commitment) were tested to predict turnover intention among employees in the company. Results from the study reveal that only affective commitment is significantly negatively related to turnover intention. The findings were discussed and implications were also put forward.
\end{abstract}

Keywords: Turnover intention, organizational support, organizational commitment, affective commitment, continuance commitment.

\section{Introduction}

Employee turnover has become a serious management problem because of its financial and moral impacts on the organization's limited source. Today, organizations find it difficult to retain employees as a result of many baby boomers retiring from the workplace. Thus, employee turnover greatly demands the management's attention and do whatever they can to retain and motivate the existing employees.

Employee turnover is the rotation of workers around the labour market, between firms, jobs and occupation as well as between the states of employment and unemployment. Organizations 
invest big paychecks on their employees in terms of induction and training, developing, maintaining and retaining them in their organization. Therefore, managers at all levels must know how to minimize employee's turnover. It is very important to develop a full understanding of employee turnover especially the source of what determines employee turnover, the effects and the strategies that managers can put in place in order to minimize turnover.

In this globalized and high competitive world, organizations must continue to develop tangible products and provide services which are based on strategies created by employees. These employees are extremely crucial to the organization since their value to the organization is essentially intangible and not easily replicated. For that reason, managers should recognize employees as major contributors to the efficient achievement of the organization's success. Managers also should control employee turnover for the benefit of the organization's success.

According to a survey conducted by Towers Watson Malaysia, turnover rate across industries in Malaysia has increased from $12.3 \%$ in 2012 to $13.2 \%$ in 2013. The survey also reported that in 2013 manufacturing, conglomerates and financial service industries were among the industries that experienced high employee turnover. The manufacturing sector had the highest turnover rate at $24 \%$, and this was followed by the financial services at $13.3 \%$. In the manufacturing sector, the Malaysian Employees Federation (MEF) reported that the highest turnover rate was in the industries involving basic and fabricated metallic products $(23.88 \%)$, electrical and electronics $(23.04 \%)$ and plastic/ rubber $(19.92 \%)$ (Goh, 2012).

Therefore, the main aim of this study is to investigate the factors that might contribute to employee turnover intention in manufacturing industries which mainly focus on organizational support and organizational commitment. It is hoped that through the examination of these two factors, more understanding on what contributes to the turnover problem can be uncovered and appropriate action can be taken.

\section{Literature Review}

\section{Turnover Intention}

In the scholarly literature, turnover intention has been defined in several ways but shared a common term (Cotton \& Tuttle, 1986). 
Generally, it refers to an individual's perceived probability of staying or leaving an employing organization. Hellman (1997) for example, defined turnover intention as the behavioural intentions illuminating an individual's intention to leave or stay and is considered to be the primary antecedent or actual turnover behaviour. Bigliardi, Petroni and Ivo Dormio (2005) used the term "intention to leave" to refer to individuals' perceived likelihood that they would be staying or leaving the employer organization.

Empirical studies on turnover have shown that turnover intention is the best immediate predictor of actual turnover behaviour (Griffeth, Hom \& Geatner, 2000). Indeed, there is a strong and significant positive relationship between turnover intention and actual turnover (Lambert, Hogan, \& Barton, 2001). However, in the review of antecedents to turnover, Mor Barak, Nissly and Levin (2001) argued that many studies have used turnover intention rather than actual turnover as the work outcomes because employees typically make conscious decisions before actually quitting their jobs and it is more practical to inquire from employees their intention to quit in a cross-sectional study rather than actually tracking them down via a longitudinal study to see if they have left their organization. For those reasons and consistent with previous research (e.g. Lambert et al., 2001; Price, 2001), turnover intention is the criterion variable in this study since it has recommended as a proxy in measuring actual turnover. Thus, turnover intention is clearly defined as employees' behavioural intention to leave or quit their particular organization.

\section{Organizational Support and Turnover Intention}

In the past, studies have shown how organizational support influence turnoverintention. Tumwesige(2010)forexample, found thatemployees who perceive lack of support from their organization will feel less committed to their organization and thus, lead to turnover intention. A study conducted by Valentine, Greller and Richtermeyer (2006), found that organizations can build employees' positive perceptions of the workplace by emphasizing ethical practices that support the welfare of stakeholders and that increases congruence between personal and organizational values. Such perception is associated with turnover intention.

Allen, Shore and Griffeth (2003) found that perceptions of supportive HR practices (participation in decision-making, growth opportunities, and fairness of rewards/recognition) were related to employee 
intention to leave. They further argued that when employees perceived organizational HR practices as supportive, their affective attachment to the organization would increase, and thus, decrease the intention to leave the organization. In another study, Jung (2010) also found similar findings when pay was tested against turnover intention. He found that employees who were satisfied with their pay had lower intentions to quit. His study supported earlier studies conducted by Shaw, Delery, Jenkins and Gupta (1998) and Lambert, Hogan and Barton (2001). Apart from pay, studies conducted by Shaw et al. (1998) and Jung (2010) also showed the relationship between promotion and turnover intention. In both studies, employees who were satisfied with the promotion opportunity provided by their organization tended to have lower turnover intention.

Sharing the same view, Jawahar and Hemmasi (2006) also agree that organizational support is related to turnover intention. In their study, they found that perceptions of lack of organizational support for women's advancement were related to turnover intention. To women who were aspiring to senior management positions, the extent to which the organization supported advancement wouldl be more of a concern than the general construct of organizational support.

In another study, $\mathrm{Ng}$ (2009) found that the perceptions of organizational support and external prestige are important to employees' perceptions of the quality of their exchange relationships with their organizations. The results suggest that these perceptions affect employees' work attitudes and behaviours indirectly through the quality of exchange relationships with their organization. Employees reciprocate the organization's cares and recognitions by developing trust in the organization and reducing their intention to leave the company.

In a study on repatriate, similar results were also found. Lazarova and Caligiuri found that repatriates who perceive higher levels of organizational support have lower intentions to leave their organization. They believed that company-wide appreciation of global experience and career-planning sessions were the most important elements in an MNC's repatriation system. The lack in the repatriation system will most likely generate unfavourable attitudes towards the company and will, ultimately, lead to turnover. Based on the discussion, the following hypothesis is proposed: 


\section{Organizational Commitment and Turnover Intention}

Organizational commitment refers to how strong is the individual's identification with and involvement in a particular organization (Mowday, Porter, \& Steers, 1982). They argued that organizational commitment normally possesses characteristics like having a strong belief in and acceptance of the organization's goals and values; a willingness to put high effort for the organization; and a strong desire to remain with the organization. Hulin (1991) in his writing has described organizational commitment as "a construct that seeks to explain consistencies involving attitudes, beliefs and behaviour; involves behavioural choices and implies a rejection of feasible alternative courses of action." In another writing, Meyer and Allen (1991) have divided organizational commitment into three categories, namely affective, continuance and normative commitments. They define affective commitment as the feelings of belonging and sense of attachment to the organization. These related to personal characteristics, organizational structures, and work experiences, such as pay, supervision, role clarity, and skill variety. On the other hand, continuance commitment is about the costs of leaving, both financial and non-financial and perceived lack of alternatives, whereas normative commitment is the feelings of obligation towards continued employment.

Past studies have shown that organizational commitment can influence turnover intention among employees in an organization. For example, Blau and Boal (1989) found that employees with lower levels of job involvement and organizational commitment are in the "highest risk" category for subsequent turnover, with employees having high job involvement and low organizational commitment being next in terms of turnover risk. Pare, Tremblay and Lalonde (2001) found that organizational commitment not only mediates but also moderates the effects of HR practices on quit intentions.

In another study, Cohen (1993) found that job withdrawal intentions are affected negatively by job satisfaction and job commitment, but positively by organizational commitment. He also found that age factor also affected the intention to leave. For instance, he found that compared to young employees, though older employees reported low levels of organizational commitment, they didn't leave the organization because of structural bonds, few employment alternatives and a desire for stability. 
In another study on organizational commitment, Cole and Bruch (2006) found that officers and middle-management who are affectively attached to the organization (i.e. commitment) have low interests in seeking other employment. However, commitment among lower hierarchical levels (non-management employees) did not influence workers' desire to remain or leave the organization.

Apart from that, organizational commitment and intention to stay were significantly related to person-organization fit, and remuneration and recognition (Chew \& Chan, 2008). In terms of types of commitment, affective commitment appears to be more salient in predicting intent to turnover than continuance commitment, and a high level of continuance commitment may help employees rationalize an emotional, affective attachment to an organization (Law, 2005). Pare and Tremblay (2004) also found that strong affective commitment motivates individuals to construe their work role as extending beyond tasks formally prescribed, which in turn encourages them to adopt extra role behaviours and be negatively related to quit intentions. The result of this study also indicate that continuance commitment is also associated with turnover intentions, since employees are likely to stay with their organization not only when they have an emotional attachment to their organization but also when they perceive the cost of leaving.

Perryer, Jordan, Firns and Travaglione (2010) found that employees may be less likely to leave their organization as their levels of affective commitment increase in conjunction with an increase in support provided by the organization. Similarly, Stallworth (2003) also found that affective commitment demonstrates the strongest relationship with turnover. The results of this study also indicate that affective commitment may be the best predictor of intentions to leave at lower organizational levels, while continuance commitment becomes increasingly important as employees move up the ladder. Thus, the following hypotheses are proposed:

H2: Affective commitment is negatively related to turnover intention H3: Continuance commitment is negatively related to turnover intention

\section{Methodology}

\section{Participants}

105 participants (63 males, 42 females) from a manufacturing company participated in this study. The average age of the respondents was 
31 years old. Malays constituted $77.1 \%$ of the survey respondents, followed by $14.3 \%$ Malaysian Chinese and 8.6\% Malaysian Indians. Engineers made up $40 \%$ of the total number of respondents. The rest consisted of administrative and other technical staff. On the average, the respondents had been in their present position for almost 5 years and had served their organization for more than 3 years. The majority of the respondents in this survey $(90.5 \%)$ had higher academic qualifications of either a diploma, first or second degree.

\section{Measurements}

Turnover intention was the dependent variable and the measure was adapted from Lee (2008). The 5-item scale asked respondents about their probability of staying or leaving the organization. Organizational support and organizational commitment were the independent variables tested in this study. Organizational support was assessed using the 10-item scale adapted from Perryer, Jordan, Firns and Travaglione (2010) where respondents were asked about their perceptions of supportive HR practices in terms of participation in decision-making, growth opportunities, and fairness of rewards/ recognition. Organizational commitment was measured by two dimensions, affective commitment and continuance commitment. The 16-item scale adapted from Allen and Meyer (1990) asked about the respondents' perception of emotional attachment to or identification with the organization and their willingness to remain in the organization because of the investment that the employees had with "nontransferable" investments. In this study, each of the adapted questions asked how strongly the respondents agreed or disagreed with the statement given on a five-point scale whereby, $1=$ strongly disagree and $5=$ strongly agree.

\section{Findings}

\section{Correlation Analysis}

Table 1 presents the means, standard deviations and Pearson correlations of the variables for the 105 participants. The internal consistency reliabilities (Cronbach's alpha) of the research measures are reported in parenthesis. As shown in Table 1, the Cronbach's alpha for organizational support was 0.96 , and for the organizational commitment it was 0.72. The two components of organizational commitment (affective commitment and continuance commitment) 
also had satisfactory reliability values of 0.83 and 0.66 respectively. The Cronbach's alpha for turnover intention was 0.86 .

Table 1 reveals that organizational support was significantly negatively correlated with turnover intention $(\mathrm{r}=-0.575, \mathrm{p}<0.01)$. This result implies that, the more the support given by the organization, the less the intention to leave the organization.

Overall, organizational commitment was significantly negatively correlated with turnover intention $(\mathrm{r}=-0.619, \mathrm{p}<0.01)$. Table 1 also reveals significant negative relationships between affective commitment and turnover intention $(\mathrm{r}=-0.700, \mathrm{p}<0.01)$, while continuance commitment was not significantly negatively correlated to turnover intention. The results suggest that participants with higher feelings of affective commitment towards their organization have less intention to leave.

Table 1

Descriptive Statistics, Scale Reliabilities, and Correlations of Variables

\begin{tabular}{|c|c|c|c|c|c|c|c|c|c|}
\hline & Variables & $\mathrm{N}$ & Mean & S.D. & 1 & 2 & 3 & 4 & 5 \\
\hline 1. & $\begin{array}{l}\text { Organizational } \\
\text { support }\end{array}$ & 105 & 3.68 & 0.830 & $(0.96)$ & & & & \\
\hline 2. & $\begin{array}{l}\text { Org. commitment } \\
\text { (overall) }\end{array}$ & 105 & 3.38 & 0.430 & $0.680^{* *}$ & $(0.72)$ & & & \\
\hline 3. & $\begin{array}{l}\text { Affective } \\
\text { commitment }\end{array}$ & 105 & 3.32 & 0.657 & $0.779^{* *}$ & $0.772^{* *}$ & $(0.83)$ & & \\
\hline 4. & $\begin{array}{l}\text { Continuance } \\
\text { commitment }\end{array}$ & 105 & 3.45 & 0.547 & 0.134 & $0.646^{* *}$ & 0.014 & $(0.66)$ & \\
\hline 5. & Turnover intention & 105 & 2.70 & 0.881 & $-0.575^{* *}$ & $-0.619^{* *}$ & $-0.700^{* *}$ & -0.134 & $0(.86)$ \\
\hline
\end{tabular}

\section{Regression Analysis}

To test hypotheses 1, 2 and 3, regression analysis was conducted. The result shown in Table 2 indicates that $50.5 \%\left(R^{2}=0.505, F\right.$ value $=34.41$ $\mathrm{p}<0.001$ ) of the variance in turnover intention has been significantly explained by organizational support, affective commitment and continuance commitment. However, in the model, only the affective commitment factor was found to be negatively associated with turnover intention $(\beta=-0.67, \mathrm{p}<0.001)$. Therefore, only hypothesis 2 was supported. 
IJMS 22 (1), 33-45 (2015)

Table 2

Regression Results of Organizational Support, Affective Commitment and Continuance Commitment on Turnover Intention

\begin{tabular}{lcccc}
\hline \multicolumn{1}{c}{ Independent variables } & $\begin{array}{c}\text { Dependent variable } \\
\text { (Turnover intention) } \\
\text { (Standardized Beta) }\end{array}$ & $\begin{array}{c}\text { Significant } \\
(p)\end{array}$ & Tolerance & VIF \\
\hline Organizational support & -0.04 & 0.74 & 0.38 & 2.65 \\
Affective commitment & -0.67 & $0.00^{* *}$ & 0.38 & 2.60 \\
Continuance commitment & -0.12 & 0.10 & 0.96 & 1.04 \\
\hline F value & 34.41 & & & \\
$\mathrm{R}^{2}$ & 0.505 & & & \\
Adjusted $\mathrm{R}^{2}$ & 0.491 & & & \\
\hline Note. & ${ }^{* *} \mathrm{p}<0.001$ & & &
\end{tabular}

\section{Discussion}

The current empirical findings suggest that only affective commitment is negatively associated with turnover intention. Though in the previous study affective commitment was found to be the best predictor of intention to leave among the lower level of employees in the organization (e.g. Stallworth, 2003), the current findings reveal that affective commitment is the significant predictor of intention to leave among the high or level of employees such as the engineers. Interestingly, the current findings indicate that employees' emotional bond to the organization the important determinant of dedication and loyalty regardless of the level of position within the organization.

One possible reason why affectively committed employees have less intention to leave the organization is because they themselves want to stay with their organization. The positive work experience that the employees received like support from the supervisors and peers, the working condition, policies and administrative practices, salary and benefits, job security and personal life contribute to the emotional attachment to the organization. Besides, Meyer and Allen (1991) and Mowdday, Porter and Steers (1982) argued that affectively committed employees are those who have a sense of belonging and identification with the organization, who are highly involved with the organization's activities, who are willing to pursue the organization's goals and who have the desire to remain with the organization. 
Therefore, it is not surprising to see those who had higher affective commitment had lower intention to leave even if other organizations had attractive employment packages to offer.

\section{Limitation of Study and Direction for Future Research}

There are limitations in the design of this study that might influence the interpretations and generalizations of these findings. In understanding the factors that might be related to turnover intention, the study only tested two predictors which were organizational support and organizational commitment. Apart from that, the data was collected from one type of industry and located in a specific geographic location.

Given the findings and acknowledging the limitations of the present study, several areas of potential research exist. Since the study only tested two variables in predicting turnover intention, perhaps in future research, it may be worth investigating other variables such as organizational climate, leadership style, role ambiguity and role conflict that may influence the turnover intention, which were not considered in this study. There is also a need for future research to extend the exploration on turnover intention to other kinds of industries such as in the services, medical settings, academia as the data provided in this study was from one type of industry and was located in a specific geographic location. While there are some limitations associated with the approach used here and given the exploratory nature of the study, the results of this research provide useful findings that should be of interest to both researchers and practitioners.

\section{Implications of the Study}

The present findings have several implications for the management of the organizations. The research results revealed that affectively committed employees tend to have lower intention to leave the organization. Based on the findings, the management of the organization needs to continually enhance their organizational support by allowing employees to participate in decision making, providing developmental activities, encouraging employees' with fair rewards, acknowledging employees' contribution and providing an extensive two-way communication among all levels of management. 
By having this kind of healthy culture in the organization, employees will have more sense of belonging to the company, thus preventing them from leaving the organization.

\section{Conclusion}

The aim of this study was to examine factors that might relate to turnover intention. The current research findings indicate that only affective commitment is significantly negatively related to turnover intention. Since the study was conducted in one organization only, the findings must be interpreted with caution and cannot be generalized to represent other organizations. It is hoped that through the examination of the factors that are related to turnover intention, a more complete understanding of the kind of effort needed to enhance employee retention will be achieved.

\section{References}

Allen, N. J., \& Meyer, J. P. (1990). The measurement and antecedents of affective, continuance and normative commitment to the organization. Journal of Occupational Psychology, 63, 1-18.

Allen, D. G., Shore, L. M., \& Griffeth, R. W. (2003). The role of perceived organizational support and supportive human resource practices in the turnover process. Journal of Management, 29(1), 99-118.

Bigliardi, B., Petroni, A., \& Ivo Dormio, A. (2005). Organizational socialization, career aspirations and turnover intentions among design engineers. Leadership $\mathcal{E}$ Organization Development Journal, 26(6), 424-441

Blau, G., \& Boal, K. (1989). Using job involvement and organizational commitment interactively to predict turnover. Journal of Management, 15(1), 115-127

Chew, J., \& Chan, C. C. A. (2008). Human resource practices, organizational commitment and intention to stay. International Journal of Manpower, 29(6), 503-522.

Cohen, A. (1993). Organizational commitment and turnover: A metaanalysis. Academy of Management Journal, 36(5), 1140-1157.

Cole, M. S., \& Bruch, H. (2006). Organizational identity strength, identification, and commitment and their relationships to turnover intention: Does organizational hierarchy matter? Journal of Organizational Behavior, 27, 585-605. 
Cotton, J., \& Tuttle, J. (1986). Employee turnover: A meta-analysis and review with implication for research. Academy of Management Review, 11(1), 55-70.

Griffeth, R. W., Hom, P. W., \& Gaertner, S. (2000). A meta-analysis of antecedents and correlates of employee turnover: Update, moderator tests, and research implications for the next millennium. Journal of Management, 26(3), 463-489.

Goh, L. (2012, Feb 12). Why job-hoppers hop. The STARonline. Retrieved from http://www.thestar.com.my/News/Nation/2012/02/19/ Why-jobhoppers-hop/

Hellman, C. M. (1997). Job satisfaction and intent to leave. Journal of Social Psychology, 137(6), 667-689.

Hulin, C. (1991). Adaptation, persistence, and commitment in organizations. In M. D. Dunnette \& L. M. Hough (Eds.), Handbook of Industrial and Organizational Psychology, Vol. 2, Palo Alto, CA: Consulting Psychologists Press.

Jawahar, I. M., \& Hemmasi, P. (2006). Perceived organizational support for women's advancement and turnover intentions. Women in Management Review, 21(8), 643-661.

Jung, C. (2010). Predicting organizational actual turnover rates in the U.S. federal government. International Public Management Journal, 13(3), 297-317.

Lambert, E. G., Hogan, N. L., \& Barton, S. M. (2001). The impact of job satisfaction on turnover intention: A test of a structural measurement model using a national sample of workers. The Social Science Journal, 38, 233-250.

Law, D. W. (2005). Interactive organizational commitment and hardiness in public accountants' turnover. Managerial Auditing Journal, 20(1), 383-393.

Meyer, J., \& Allen, N. (1991). A three component conceptualization of organizational commitment. Human Resource Management Review, 1, 61-89.

Mor Barak, M. E., Nissly, J. A., \& Levin, A. (2001). Antecedents to retention and turnover among child welfare, social work, and other human service employees: What can we learn from past research? A review and meta-analysis. The Social Service Review, 75(4), 625-661.

Mowday, R., Porter, L., \& Steers, R. (1982). Employee-organization linkages: The psychology of commitment, absenteeism, and turnover. New York: Academic Press.

$\mathrm{Ng}$, M. (2009). Unraveling the relationship between employees' perception to organization and turnover intentions: Exploring the mediating effects of trust to organization. Retrieved from http://academicpapers.org/ocs2/session/Papers/F7/851-2141-1-DR.doc 
Pare, G., Tremblay, M., \& Lalonde, P. (2001). The role of organizational commitment and citizenship behaviors in understanding relations between human resources practices and turnover intentions of IT personnel. Retrieved from http://ideas.repec.org/p/cir/ cirwor/2001s-24.html

Paré, G., \& Tremblay, M. (2004). The influence of high-involvement human resources practices, procedural justice, organizational commitment and citizenship behaviors on information technology professionals' turnover intentions. HEC Montréal, $4(17), 1-33$.

Perryer, C., Jordan, C., Firns, I., \& Travaglione, A. (2010). Predicting turnover intentions, the interactive effects of organizational commitment and perceived organizational support. Management Research Review, 33(9), 911-923.

Price, J. L. (2001). Reflections on the determinants of voluntary turnover. International Journal of Manpower, 22(7), 600-624.

Shaw, J. D., Delery, J. E., Jenkins, Jr., G. D., \& Gupta, N. (1998). An organization-level analysis of voluntary an involuntary turnover. Academy of Management Journal, 41(5), 511-525.

Stallworth, H. L. (2003). Mentoring, organizational commitment and intentions to leave public accounting. Managerial Auditing Journal, 18(5), 405-418.

Tumwesigye, G. (2010). The relationship between perceived organizational support and turnover intentions in a developing country: The mediating role of organizational commitment. African Journal of Business Management, 4(6), 942-952.

Valentine, S., Greller, M. M., \& Richtermeyer, S. (2006). Employee job response as a function of ethical context and perceived organization support. Journal of Business Research, 59, 582-588 